\title{
170 lat realizacji systemu ochrony przez wychowanie w koncepcji Edmunda Bojanowskiego
}

\begin{abstract}
Edmund Bojanowski's concept

The pedagogical thought and concept of the system of protection by Edmund Bojanowski's upbringing, even though it was born 170 years ago, appears today to be innovative and exceptionally up-to-date. Applied in contemporary pre-school education and child care, it is a continuation of the concept of upbringing and its practical implementation by establishing on May 3, 1850 the nursery and Congregation of the Servant Sisters. The theoretical and practical application of this concept and new research and scientific studies on the essence of early education realized in Catholic pedagogical thought in the context of contemporary civilization challenges is still expected from various circles in Poland and worldwide.
\end{abstract}

Keywords: child, integral education, system of protection, nursery, Edmund Bojanowski, Congregation of the Servant Sisters

Myśl pedagogiczna i koncepcja systemu ochrony przez wychowanie Edmunda Bojanowskiego, mimo że zrodziła się 170 lat temu, jawi się dzisiaj jako nowatorska i wyjątkowo aktualna. Zastosowana we współczesnej edukacji przedszkolnej i opiece nad dzieckiem jest kontynuacją działań koncepcji wychowania i jej praktycznej realizacji przez założenie 3 maja 1850 r. ochronki i Zgromadzenia Sióstr Służebniczek. Z różnych środowisk w Polsce i na świecie wciąż oczekiwana jest teoretyczna i praktyczna aplikacja tej koncepcji oraz nowych badań i opracowań naukowych dotyczących istoty wczesnej edukacji realizowanej w katolickiej myśli pedagogicznej w kontekście współczesnych wyzwań cywilizacyjnych. 
Rozwijające się dzieło tworzenia instytucji ochronek zapoczątkowane w Europie już w drugiej połowie XVIII w. znalazło swoich realizatorów również na terenie Polski, między innymi w osobie Edmunda Bojanowskiego (1814-1871). Szczególne znaczenie miała jego koncepcja ochrony jako czynności i jako instytucji, którą tworzył, odnosząc się do dorobku przeszłości oraz doświadczeń twórców instytucji ochron w innych krajach i na ziemiach polskich. 3 maja 1850 r. otworzył pierwszą ochronkę wiejską w Podrzeczu w Wielkopolsce. Ten dzień jest również początkiem Zgromadzenia Sióstr Służebniczek NMP, które założył dla prowadzenia ochron. Biorąc pod uwagę społeczno-kulturowe i polityczne uwarunkowania, stworzył system ochrony opierający się na działaniach opiekuńczo-wychowawczych i oświatowych o jasnej podstawie chrześcijańskiego humanizmu. Jako taki realizowany jest do dzisiaj od 170 lat przez Siostry Służebniczki w Polsce i różnych krajach świata, bez szkody dla jego tożsamości mimo dostosowywania jej do aktualnych potrzeb.

\section{Kontekst biograficzny inspiracji i tworzenia koncepcji ochron}

Edmund Bojanowski urodził się 14 XI 1814 r. w Grabonogu w rodzinie ziemiańskiej o bogatych tradycjach narodowych i patriotycznych oraz głęboko religijnej. Pielęgnowanie tradycji narodowej, właściwe polskim dworom, twórczo działało na jego umiłowanie historii ojczystej, języka i literatury ${ }^{1}$. Ze względu na swe zdolności intelektualne, od 1832 r. podjął studia we Wrocławiu na wydziale filozoficznym, gdzie oddał się studiowaniu dzieł romantycznych i słowianofilstwa. Potem studiował na uniwersytetach w Dreźnie i Berlinie. W okresie studiów nawiązał liczne kontakty z przedstawicielami polskiej kultury, m.in. z Adamem Mickiewiczem, Ludwikiem Gąsiorowskim, Antonim Odyńcem, Janem Nepomucenem Bobrowiczem².

Bojanowski w tym czasie doświadczył też wielu trudnych przeżyć związanych ze śmiercią najbliższych i własną chorobą, która nie pozwoliła mu kontynuować nauki. W 1838 r. musiał opuścić uniwersytet w Berlinie i wrócił do Wielkiego Księstwa Poznańskiego, a zamieszkawszy w Grabonogu, oddał się pracy oświatowej. Od samego początku włączał się czynnie w życie kulturalne i społeczne ziemi gostyńskiej, przede wszystkim jako członek Wydziału Literackiego Kasyna Gostyńskiego. Zbierał i gromadził materiały o wartości literackiej i wychowawczej. Podania, piosenki, przysłowia, zwyczaje oraz wskazania na wartość ich dla kultury polskiej i zastosowania w edukacji stanowią bogaty materiał jego zbiorów. Publikował je także w „Przyjacielu Ludu”, „Roku Wiejskim”, „Pokłosiu”.

\footnotetext{
${ }^{1}$ Zachował się bogaty materiał źródłowy, z którego poznajemy życie, intencje, myśl pedagogiczną, jej rozwój i działania E. Bojanowskiego, jest nim: Korespondencja Edmunda Bojanowskiego z lat 1829-1871, t. 1-2, objaśnił, skomentował i zarysem monograficznym poprzedził L. Smołka, Wrocław 2001; E. Bojanowski, Dziennik, objaśnił, skomentował i wstępem poprzedził L. Smołka, t. 1-4, Wrocław 2009.
}

2 Zob. A. Szelęgiewicz, Edmund Bojanowski i jego dzieło, Księgarnia św. Wojciecha, Poznań-WarszawaLublin 1966, s. 11-12. 
W 1843 r., aby zapobiegać analfabetyzmowi Bojanowski przystąpił wspólnie z innymi członkami Kasyna Gostyńskiego do zakładania czytelni ludowych. Obok akcji oświatowej inspirowany przez niego Wydział Literacki Kasyna podjął działalność wychowawczą wśród ludu polskiego, w której ważną rolę miały odegrać ochronki wiejskie $^{3}$. Działał intensywnie, lecz nie pochopnie. Najbardziej strategiczne rozwiązania dojrzewały w nim bardzo długo. Najpierw zatem zgłębiał istotę wychowania, analizując jego dzieje od starożytności, a odnosząc się do przyjętych już na Zachodzie rozwiązań, próbował rozwijać koncepcję ochron odpowiednią polskim warunkom. Razem z L. Gąsiorowskim w 1844 r. założyli ochronkę w Poznaniu, a rok później w Gostyniu, dla której napisał statut ${ }^{4}$. Prawdopodobnie przy dużym jego udziale zostały wydane wskazówki dla opiekunek, które odwiedzały domy ochronek, sprawując nad nimi dozór ${ }^{5}$. Zapiski $\mathrm{w}$ notatkach ${ }^{6}$ dotyczące wychowania oraz organizacji takich instytucji na Zachodzie wskazują na to, że konsekwentnie zmierzał do stworzenia własnego systemu wychowania w ochronie. Korzystał umiejętnie z różnych doświadczeń i rozwiązań praktycznych, dokonując syntezy tego, co było godne uznania, kierując się zasadą synergii dobrej i spójnej teorii oraz dobrze zorganizowanej praktyki wychowawczej.

W 1849 r. Gostyń i okolice nawiedziła epidemia cholery. Budynek dawnego kasyna przekształcony został na dom dla ubogich chorych, który Bojanowski nazwał Instytutem, a jego prowadzenie powierzył Siostrom Miłosierdzia. Potem według statutu celem Instytutu była opieka nad chorymi, sierotami i ubogimi dziećmi. Bojanowskiemu chodziło również o to, by oprócz chleba dawać dzieciom serce, zapewnić im wychowanie i przygotować je do życia. Za szczególnie istotne uważał przyzwyczajenie dzieci do życia z pracy własnych rąk. W tym celu wydzierżawił kawałek ziemi, zbudował budynki gospodarcze, założył sad, ogród warzywny i kwiatowy. Poprzez pracę w polu, ogrodzie i domu dzieci nabywały zamiłowanie do pracy i porządku. Sam poświęcał im wiele czasu, uczył je, pracował razem z nimi, oddziaływał na nie swoją bogatą osobowością. Do wychowania narodowego i religijnego przywiązywał ogromną wagę ${ }^{7}$.

Okres działalności Bojanowskiego w Kasynie i Instytucie to czas ciągłych poszukiwań sposobu pracy z ludem i dla ludu, możliwość otoczenia go opieką, udzielania pomocy w odnowie moralnej i kulturalnej, a dzieciom zapewnienie dobre wychowanie.

3 Zob. P. Gołdyn, Edmund Bojanowski (1814-1871) - szkic biograficzny, „Zeszyty Naukowe KUL” 2017 (60), $\mathrm{nr}$ 4(240), s. 17-23.

${ }^{4}$ Zob. M. Fąka, Ziarno wrzucone w ziemię, wydano staraniem Sióstr Służebniczek NMP, Wrocław 1988, s. 101.

5 Skazówka dla opiekunek odwiedzających domy ochrony, Poznań 1844.

${ }^{6}$ Dokonano krytycznej edycji rękopisów jego notatek i opublikowano: Prace, szkice i notatki Edmunda Bojanowskiego. Inedita, t. I-II, red. E. Gigilewicz, M. Opiela, Prace Instytutu Leksykografii KUL 4; Kompendium edukacyjne Edmunda Bojanowskiego, red. M.L. Opiela, Wydawnictwo Episteme, Lublin 2016.

7 Zob. A. Szelęgiewicz, op. cit., s. 34-39. 
Znajomość środowiska wiejskiego oraz orientacja w ówczesnej sytuacji uzasadniały potrzeby zakładania ochronek na wsi ${ }^{8}$.

Bojanowski znał Augusta Cieszkowskiego i jego koncepcję ochronek wiejskich ${ }^{9}$. Porównując ją z potrzebami i warunkami wsi wielkopolskiej oraz opierając się na swoim dotychczasowym doświadczeniu w udzielaniu pomocy dzieciom i trudnościach związanych z jej realizacją, postanowił powierzyć wychowanie dzieci wiejskich młodym dziewczętom spośród ludu. W dniu 3 maja 1850 r., przy współpracy z gospodynią wiejską Franciszką Przewoźną, założył pierwszą ochronkę wiejską w Podrzeczu k. Gostynia w Wielkim Księstwie Poznańskim ${ }^{10}$. Od tej pory wcielał w życie i doskonalił swą koncepcję pedagogiczną, zakładając jednocześnie zgromadzenie zakonne Sióstr Służebniczek NMP jako kadrowe zaplecze dla jej realizacji.

\section{Uwarunkowania społeczno-historyczne tworzenia koncepcji i zakładania ochronek wiejskich przez E. Bojanowskiego}

Społeczno-kulturowe i polityczne uwarunkowania ówczesnej sytuacji wymagały odpowiadających im stałych, profesjonalnych działań, służących dobru osób, rodzin i narodu, zachowaniu jego kultury i tożsamości. Bojanowski uwzględniał więc zależności między tym, co niezmienne i co stanowi stały punkt odniesień, źródło celów, zasad i zapewnia ciągłość działaniom, a tym, co zmienne i co gwarantuje rozwój, adaptację oraz realizację celów w zmieniających się warunkach miejsca i czasu. Tworząc takie podstawy dziełu ochron i prowadzonej w nich działalności, zapewnił mu właściwą dynamikę potrzebną do współmiernego odpowiadania na bieżące potrzeby i problemy zmieniającej się rzeczywistości oraz zapewniającą jego ciągłość i przewidywalnośćl1. Szczególnie ważne to było dla ubogiej i zaniedbanej społeczności wsi polskiej,

Dzięki prowadzonej działalności Bojanowski poznał całą nędzę materialną i moralną ludu wiejskiego. Odkrył skalę problemu sierot i dzieci z ubogich rodzin wiejskich, które pozostawały bez opieki i były narażone na niebezpieczeństwa zagrażające ich życiu i rozwojowi. Nade wszystko pragnął zaradzić potrzebom wsi polskiej poprzez tworzenie ochronek i włączanie do służby w nich wiejskich dziewcząt. Nie działał pochopnie ani doraźnie, ale podejmował głęboką refleksję nad systemowym rozwiązaniem problemów. Tak stworzył system ochrony przez wychowanie i dał przykład stylu jego twórczej realizacji.

\footnotetext{
${ }^{8}$ Zob. ibidem, s. 29.

9 A. Cieszkowski, O ochronach wiejskich, Poznań 1842.

10 Zob. M. Fąka, op. cit., s. 44.

11 Przemiany tej działalności zostały przeanalizowane w istotnych wymiarach, wyodrębniono obszary kontynuacji i zmiany, ważne dla właściwego podejmowania zmian adaptacyjnych: M. Opiela, Dynamika przemian działalności opiekuńczo-wychowawczej Sióstr Stużebniczek BDNP w ochronkach, Zgromadzenie SSł. BDNP, Dębica 2011.
} 
Mimo zaborów i prześladowań ze strony zaborców Bojanowskiemu nie chodziło o izolację od nich. Korzystał z dorobku rozwijającej się myśli pedagogicznej i tworzonych rozwiązań praktycznych szczególnie w dziedzinie wczesnej edukacji i opieki nad dziećmi. Czerpał z doświadczeń i wiedzy, ale nie bezkrytycznie, lecz z uwzględnianiem rodzimych potrzeb i specyfiki kulturowej. Dociekliwie studiował literaturę filozoficznopedagogiczną rodzimą i obcojęzyczną, nawiązując do współczesnych sobie myślicieli i przedstawicieli rozwijającej się teorii i praktyki pedagogicznej. Zgłębiał przejawiające się w kulturze i społeczeństwach Europy zjawiska, sięgając do dorobku przeszłości i doświadczeń ludzkości w dziedzinie wychowania, sam tworząc i działając praktycznie. Stąd wyciągał wnioski służące rozwijaniu trwałej i elastycznej koncepcji ochron, zapewniając także zaplecze organizacyjne i kadrowe. $\mathrm{Z}$ zachowanych rękopisów notatek E. Bojanowskiego służebniczki mogły wciąż odczytywać je na nowo, by określić teoretyczne podstawy wychowania w kontekście ich praktycznej realizacji ${ }^{12}$. Na tej podstawie został opracowany program wychowania przedszkolnego ${ }^{13}$ oraz pedagogika przedszkolna $\mathrm{w}$ jego koncepcji ${ }^{14}$.

E. Bojanowski cenił to, co zostało rzetelnie opracowane teoretycznie i sprawdzone w praktyce. Ważną inspiracją dla niego i dla rozwoju ochronek jako rodzimych instytucjonalnych form wychowania małego dziecka była postępowa myśl pedagogów i projektodawców oświatowych Komisji Edukacji Narodowej, którzy postulowali tworzenie takich form wychowania i objęcie ich opieką przez państwo ${ }^{15}$. Odwoływał się do autorytetów i korzystał z dorobku tych, którzy podobnie jak on poszukiwali sposobów odrodzenia rzeczywistości z przekonaniem, że

im groźniej teraźniejsze stosunki społeczne chwieją się z braku podstawy moralnej, tym żywotniejszym staje się zadaniem ludzkości sprawa wychowania. Za nią mnogie już podnosiły się głosy. Pestalozzi, który tej sprawie całkiem się poświęcił, nie widział innego wybawienia dla upadłej ludzkości, jak jedynie tylko we wychowaniu i na tej tylko drodze spodziewał się odrodzenia ${ }^{16}$.

Sięgając do doświadczeń dorobku ludzkości od starożytności, poszukiwał ważnych wskazań dla tak rozumianej roli wychowania. Natomiast praktyczne rozwiązania

${ }^{12} \mathrm{~W}$ tym celu stopniowo powstawały kolejne prace dyplomowe i opracowania, np.: M. Smoll, Psychologiczne podstawy metod wychowawczych w systemie ochronkowym Edmunda Bojanowskiego (1814-1971), Lublin 1969 (mps); R. Niparko, System wychowania przedszkolnego Edmunda Bojanowskiego, Poznań-Wrocław 1991 (mps).

${ }_{13}$ M. Opiela, M. Kaput, E. Piekarz, A. Kornobis, Z. Zymróz, S. Chudzik, Program wychowania przedszkolnego wedlug koncepcji pedagogicznej bł. Edmunda Bojanowskiego, Zgromadzenie SSł. BDNP, Dębica 2008; II wyd. poprawione, Dębica 2015. Program ten, na życzenie realizujących go w różnych krajach świata został przetłumaczony na język hiszpański (2009) i francuski (2010), a ostatnio na język angielski (2020).

${ }^{14}$ M. Opiela, Integralna pedagogika przedszkolna w systemie wychowania Edmunda Bojanowskiego. Kontynuacja i zmiana, Wyd. KUL, Lublin 2013.

15 Zob. W. Bobrowska-Nowak, Historia wychowania przedszkolnego, Warszawa 1978, s. 74-76.

${ }^{16}$ Prace, szkice, op. cit., t. 2, s. 237. 
wczesnej edukacji zapoczątkowano w XVIII w., kiedy nastąpiło ożywienie zainteresowania problemem wychowania przedszkolnego. Wiązało się to z propozycjami wychowawczymi Jeana-Jacquesa Rousseau (1712-1778) i jego koncepcją wychowania naturalnego, oraz Johanna Heinricha Pestalozziego (1746-1827). Nie było jednak odrębnych instytucji, które zajmowałyby się wychowaniem małych dzieci poza rodziną. W $1778 \mathrm{r}$. Oberlin (1740-1826) założył w Alzacji pierwszą ochronkę, której celem było uchronienie dzieci od niebezpieczeństw w czasie pracy rodziców oraz odpowiednie przygotowanie ich do obowiązków szkolnych. Potem ruch ochronkowy rozwijał się w XVIII w. w Niemczech i Anglii. Otwarte przez Roberta Owena w 1816 r. przyfabryczne przedszkole dla dzieci w wieku 2-6 lat było wyrazem jego zrozumienia dla przygotowania dzieci do nauki szkolnej i troski o stworzenie im warunków radosnego dzieciństwa. Starał się o rozwój fizyczny dzieci, wychowanie etyczne i przygotowanie do pracy poprzez zabawę. W 1827 r. założono pierwsze ochronki w Paryżu. Były to instytucje dobroczynne zapewniające opiekę dzieciom do 6 roku życia oraz odpowiednie do ich wieku i rozwoju umysłowego wychowanie. Ważne wskazania w dziedzinie wychowania małego dziecka w XIX w. dał Friedrich Fröbel (1782-1852). Kładł on nacisk na wszechstronny rozwój dziecka, który ma się dokonywać przez instynkty: pracy, wiedzy, piękna oraz religii. Proces rozwoju dziecka powinien przebiegać harmonijnie w toku samorzutnej, swobodnej aktywności dziecka, której podstawą jest zabawa. Charakter działalności wychowawcy był bierny ${ }^{17}$.

Dzięki wykorzystaniu tego dorobku w XIX w. zaczęły na ziemiach polskich powstawać ochronki miejskie. Najpierw w Królestwie Polskim pierwszą ochronkę założono w 1842 r. w Warszawie, a jej kierownictwo powierzono Teofilowi Nowosielskiemu, który swoje postulaty wychowawcze opierał na wzorach europejskich. Instytucja ochronek w Królestwie Polskim rozwijała się szybko. Wtedy Polska, w porównaniu z innymi krajami Europy Zachodniej, była krajem rolniczym, słabo uprzemysłowionym, stąd istniała przewaga liczebna ludności wiejskiej nad miejską. W pierwszej połowie XIX w. nie było w Polsce żadnej ochronki wiejskiej. Coraz częściej jednak odzywały się głosy domagające się roztoczenia opieki wychowawczej nad biednym i opuszczonym dzieckiem wiejskim. Szczególnie nasilały się one na terenie Wielkiego Księstwa Poznańskiego.

W latach 40. nastąpiło ożywienie w dziedzinie szkolnictwa i myśli pedagogicznej w publicystyce (Hipolit Cegielski, Karol Libelt, Bronisław Trentowski), w zakresie szkolnictwa (Ewaryst Estkowski, Ludwik Urbanowicz, Ksawery Łukaszewski), w dziedzinie opieki lekarskiej nad dzieckiem i wychowania fizycznego (Michał Baliński, Teofil Matecki). Wtedy też powstały w Wielkopolsce pierwsze ochrony zakładane przez Towarzystwo Zakładania i Prowadzenia Domów Ochrony, potem Towarzystwo Dobroczynności, a także przez Ligę Polską. Publicyści wskazywali na potrzebę zakładania ochron na wsi wielkopolskiej. Jednak nieznajomość tego sposobu pracy z dziećmi powodowała zasadnicze

17 Zob. Ł. Kurdybacha, Historia wychowania, t. 2, Wydawnictwo Naukowe PWN, Warszawa 1967, s. $282-312$. 
trudności - brak wykwalifikowanych sił, brak przykładu, brak wzoru organizacyjnego były główną przeszkodą zakładania ochron na wsi ${ }^{18}$.

Po otwarciu przez Bojanowskiego dwóch pierwszych ochronek - w 1850 r. w Podrzeczu i w 1854 r. w Kopaszewie - od 1855 r. nastąpił szybki rozwój Zgromadzenia Służebniczek. Do roku 1863 powstały 22 ochronki w miejscowościach wiejskich. Zainteresowanie ochronkami służebniczek rosło również poza granicami Wielkiego Księstwa Poznańskiego, a w 1864 r. powstało kilka ochronek na terenie Królestwa. W 1861 r. założona została ochronka w Podzwierzyńcu pod Łańcutem. To, że siostry pochodziły z ludu i chciały dla ludu bezinteresownie pracować, ułatwiało im wejście w nowe środowisko. Po okresie adaptacji założono tam nowicjat, przeniesiony w 1863 r. do Starej Wsi. W 1876 r. od ministerstwa wiedeńskiego siostry otrzymały prawo istnienia i rozwoju w Galicji. Służebniczki udały się do Poręby w diecezji wrocławskiej, gdzie 12 sierpnia 1866 r. otwarto pierwszy dom z nowicjatem ${ }^{19}$. Na skutek kasaty zgromadzeń zakonnych w ramach Kulturkampfu służebniczki musiały się ukrywać albo opuścić Wielkopolskę. Tak część z nich osiadła na terenie Galicji i w 1882 r. w Dębicy powstała ochronka, a później dom generalny wraz z nowicjatem.

Po ustaniu prześladowań, służebniczki, które pozostały w Wielkopolsce, na nowo organizowały swoje wspólnoty. W ten sposób wyodrębniły się cztery Zgromadzenia Służebniczek, wywodzące się wszystkie od tego samego założyciela - E. Bojanowskiego. Po umocnieniu własnej autonomii, każde z nich uzyskało z czasem papieskie zatwierdzenie: Służebniczki wielkopolskie, starowiejskie, śląskie i dębickie. Pomimo formalnego i organizacyjnego podziału pierwotnego Zgromadzenia Służebniczek, wszystkie są złączone duchem wspólnego charyzmatu i Założyciela, a w celu jego wiernej realizacji w 1991 r. utworzyły Federację Zgromadzenia Służebniczek NMP.

\section{Założenia organizacyjne i programowe E. Bojanowskiego podstawą aktualności koncepcji ochrony przez wychowanie}

Na tle doświadczeń europejskich na polu wychowania wynikających z wielowiekowej tradycji Bojanowski dokonał wnikliwej diagnozy sytuacji współczesnych ochron i jakości prowadzonego w nich wychowania. Wyciągając wnioski z dotychczasowego dorobku, stworzył model polskiej ochrony wiejskiej, w której dzieci powinny być wychowywane zgodnie ze swą naturą. Służebniczki do dziś podejmują działalność wychowawczą, oświatową, opiekuńczą, charytatywną w ochronkach, przedszkolach i placówkach opiekuńczo-wychowawczych, w stylu, który zaproponował Bojanowski w XIX w. Zawsze były to działania kompleksowe, spójne, planowe, oparte na diagnozie

\footnotetext{
${ }_{18}$ Zob. J. Pełkowska-Turati, Instytucje przedszkolne w Wielkim Księstwie Poznańskim w latach 1842-1918 ze szczególnym uwzględnieniem wychowania fizycznego, Poznań 1969, s. 55-60.

19 Zob. P. Gołdyn, op. cit., s. 23-26.
} 
indywidualnych i społecznych potrzeb osoby i środowiska. Towarzyszy im świadomość konkretnych celów oraz przejrzystość zasad, według których się je realizuje. Zachowaniu ciągłości i kontynuacji sprzyjają elementy ponadczasowej myśli chrześcijańskiej oraz przejrzyste zasady katolickiej tradycji, wierności wartościom najwyższym i jej otwarciu na integralny rozwój osoby. Stałym elementem działalności pedagogicznej w ochronkach jest dostosowywanie i aktualizowanie oryginalnych rozwiązań tej koncepcji wychowania do czasów współczesnych.

Wierność własnej tożsamości kształtująca styl rozumienia i prawidłowej organizacji procesu wychowania, w którym nie dominują struktury, procedury i techniki działania (chociaż i te są ważne), lecz osoby oraz osobiste relacje budowane i realizowane w celu integralnego rozwoju, stanowi podstawę kontynuacji. Z tego względu opracowano wzór tej działalności i jej założenia w zmieniających się warunkach czasu i miejsca z zachowaniem dynamiki pedagogii wskazanej przez Bojanowskiego.

Założenia wychowawcze

w ochronkach modyfikowały się w związku z konkretną sytuacją i w konkretnych warunkach społeczno-historycznych. Wyodrębnienie poszczególnych elementów działalności ochronkowej - celu, podmiotu i przedmiotu, zakresu, kierunków i rodzajów podejmowanych działań w określonym czasie, pozwala opisać jej pierwotny kształt oraz ukazać jej przemiany. Skonstruowany w ten sposób wzór tej działalności stanowi odniesienie w poszukiwaniu dróg jego trwania i aktualności. Jest rzeczywistością, którą dzięki dynamizmom systemu, możemy bardziej świadomie i jeszcze skuteczniej wykorzystać wobec wyzwań współczesności.

Bojanowski uwzględnił wszystkie te elementy tworząc system o charakterze dynamicznym, co stanowi nie tylko o jego wartości, ale również daje możliwość zachowania jego trwałości w zmieniających się warunkach, dzięki zdolności do zmian adaptacyjnych, bez utraty swej tożsamości. Dynamizm temu systemowi nadaje odniesienie do celu ostatecznego i wynikających z niego norm i wartości stanowiących podstawę stałości założeń i zasad wychowawczych przy jednoczesnym rozeznawaniu aktualnych potrzeb i odpowiadaniu na nie. To zakłada elastyczność i zmienność metod, środków i form, ogólnych ram organizacyjnych i funkcjonalnych, wynikającą ze zmian stanowiących uwarunkowania wewnętrzne i zewnętrzne. Wymaga od realizujących go osób szerokiej wiedzy na temat teorii i praktyki pedagogicznej, wielkiej wrażliwości na potrzeby człowieka i troski o jego pełny rozwój. Stawia to wymaganie odpowiedzialnego i twórczego podejścia, ale skutecznie chroni przed rutyną i schematyzmem ${ }^{20}$.

Międzypokoleniowy przekaz wpisany w proces zakonnej formacji i kształcenie do nabycia właściwych kompetencji osobowych i zawodowych zapewnia zachowanie tożsamości oraz stosowne odpowiadanie na obecne potrzeby i problemy. Stąd możliwa była teoretyczna i praktyczna aplikacja tej koncepcji w odległym czasie od jej powstania i obszarze jej realizacji - współcześnie w Europie, Afryce i Ameryce Południowej. Umożliwia to jej dynamiczny charakter, gdyż mimo upływu czasu pozostaje ona wciąż

${ }^{20}$ M.L. Opiela, Pedagogia bł. Edmunda Bojanowskiego realizowana przez Siostry Stużebniczki NMP (Na przykładzie Zgromadzenia Sióstr Stużebniczek BDNP), w: Pedagogie katolickich zgromadzeń zakonnych, red. J. Kostkiewicz, Impuls, Kraków 2012, s. 465, 445-497. 
w stanie tworzenia, zachowując swą tożsamość dzięki właściwemu rozumieniu i dokonywaniu jej aktualizacji w aspekcie ciągłości i zmiany. Jest z powodzeniem wcielana w życie w złożonym kontekście uwarunkowań wielokulturowych, wyznaniowych, społecznych i politycznych dzięki kontynuacji prowadzenia według niej edukacji przez Zgromadzenie Sióstr Służebniczek założone w tym celu przez Bojanowskiego.

Realizując program wychowania przedszkolnego według koncepcji Bojanowskiego, Służebniczki korzystają z dorobku naukowego, uwzględniają specyfikę społeczno-kulturową regionu oraz obowiązujące $\mathrm{w}$ danym kraju prawo i obowiązujacy system edu$\mathrm{kacji}^{21}$. Tak przeprowadzana przez Służebniczki wczesna edukacja w różnych formach, ale według jednej koncepcji pedagogicznej opracowanej przez E. Bojanowskiego, przekracza różnice czasu, wyznania, kultury i wszelkie inne wyzwania cywilizacyjne, bo w centrum stoi osoba i szacunek dla jej godności. Jej istotą jest wychowanie całościowe i spójne, nauka życia opartego na fundamencie natury i wiary, wprowadzanie w świat kultury i wartości chrześcijańskich, miłość do ojczyzny oraz przygotowanie dziecka do podjęcia nauki w szkole. Siostry aktualizują i dostosowują działania edukacyjne do aktualnych osiągnięć nauki i obowiązującego prawa, ale nie bezkrytycznie. Czynią to na podstawie deklarowanej koncepcji i katolickiego statusu placówki, zgodnie z którymi realizują założenia programowe w celu zapewnienia wychowania integralnego. Potwierdzają to przykłady działań na rzecz integralnego rozwoju i wychowania dzieci, urzeczywistniane przez Siostry Służebniczki w wielu krajach Europy, Afryki i Ameryki Południowej oraz na różne sposoby odpowiadajace potrzebom czasów wspóczesnych.

\section{Podsumowanie}

Wartość teoretycznych założeń koncepcji E. Bojanowskiego, stanowiących podstawę edukacji dzieci i formacji wychowawców oraz porządkujących i optymalizujących praktyczne działania, wciąż jest doceniana. Dzięki zakorzenieniu ich w dorobku przeszłości, osadzeniu w dynamizmie systemu oraz wpisanego weń stylu integralnego diagnozowania, a także odpowiadania na współczesne potrzeby i problemy konkretnych środowisk pozostaje aktualną i inspirującą w wymiarze teoretycznym i praktycznym. Przykład tego stylu dał Bojanowski, który korzystał umiejętnie z różnych doświadczeń i rozwiązań praktycznych, dokonując syntezy tego, co było godne uznania. Kierował się w tym zasadą, że dobra i spójna teoria jest najlepszą i konieczną podstawą dobrze zorganizowanej praktyki wychowawczej, której badanie z kolei rozwija i doskonali teorię.

Takie postrzeganie przez Siostry istoty wczesnej edukacji w koncepcji katolickiej myśli pedagogicznej E. Bojanowskiego umożliwia realizację tych założeń w obecnych warunkach społeczno-kulturowych i religijnych. Wyrażane są uznanie i potrzeba

${ }^{21}$ Zob. M.L. Opiela, Catholic pedagogy in early childhood education: a report on a neglected field of research, „International Studies in Catholic Education”, vol. 12, no. 2(2020), s. 172-190. 
podejmowania działań w celu rozpowszechnienia dorobku myśli i praktyki pedagogicznej E. Bojanowskiego. Mają one pomagać w innowacji w edukacji oraz integracji międzypokoleniowej i międzykulturowej. Zamierzonym efektem realizowanego w tym celu projektu jest wzbogacenie warsztatu metodycznego, co przyczyni się do rozwoju działań edukacyjnych. Koncepcji ochrony przez wychowanie - mimo że od początków jej realizacji mija właśnie 170 lat - wciąż pozostaje aktualna i stanowi wzór w kwestii ochrony osoby przez wychowanie.

\section{Bibliografia}

$$
\text { Źródła }
$$

Bojanowski E., Dziennik, objaśnił, skomentował i wstępem poprzedził Leonard Smołka, t. I-IV, Wrocław 2009.

Korespondencja Edmunda Bojanowskiego z lat 1829-1871, t. I-II, objaśnił, skomentował i zarysem monograficznym poprzedził Leonard Smołka, Wrocław 2001.

Cieszkowski A., O ochronach wiejskich, Poznań 1842.

\section{Opracowania}

Bobrowska-Nowak W., Historia wychowania przedszkolnego, Warszawa 1978.

Fąka M., Ziarno wrzucone w ziemię, Wrocław 1988.

Gołdyn P., Edmund Bojanowski (1814-1871) - szkic biograficzny, „Zeszyty Naukowe KUL” 2017 (60), $\mathrm{nr} 4(240)$, s. 17-27.

Kompendium edukacyjne Edmunda Bojanowskiego, red. M.L. Opiela, Lublin 2016.

Kurdybacha S., Historia wychowania, t. II, Warszawa 1967.

Niparko R., System wychowania przedszkolnego Edmunda Bojanowskiego, Poznań-Wrocław 1991 (mps).

Opiela M., Kaput M., Piekarz E., Kornobis A., Zymróz Z., Chudzik S., Program wychowania przedszkolnego wedlug koncepcji pedagogicznej bt. Edmunda Bojanowskiego, Zgromadzenie SSł. BDNP, Dębica 2015.

Opiela M., Integralna pedagogika przedszkolna w systemie wychowania Edmunda Bojanowskiego. Kontynuacja i zmiana, Lublin 2013.

Opiela M.L., Pedagogia bt. Edmunda Bojanowskiego realizowana przez Siostry Stużebniczki NMP (Na przykładzie Zgromadzenia Sióstr Stużebniczek BDNP), w: Pedagogie katolickich zgromadzeń zakonnych, red. J. Kostkiewicz, Kraków 2012, s. 445-497.

Opiela M., Dynamika przemian działalności opiekuńczo-wychowawczej Sióstr Stużebniczek BDNP w ochronkach, Zgromadzenie SSł. BDNP, Dębica 2011.

Opiela M.L., Catholic pedagogy in early childhood education: a report on a neglected field of research, „International Studies in Catholic Education”, vol. 12, no. 2(2020), s. 172-190.

Pełkowska-Turati J., Instytucje przedszkolne w Wielkim Księstwie Poznańskim w latach 1842-1918 ze szczególnym uwzględnieniem wychowania fizycznego, Poznań 1969.

Prace, szkice i notatki Edmunda Bojanowskiego. Inedita, t. I-II, red. E. Gigilewicz, M. Opiela, Lublin 2016.

Smoll M., Psychologiczne podstawy metod wychowawczych $w$ systemie ochronkowym Edmunda Bojanowskiego (1814-1971), Lublin 1969 (mps).

Skazówka dla opiekunek odwiedzających domy ochrony, Poznań 1844.

Szelęgiewicz A., Edmund Bojanowski i jego dzieło, Poznań-Warszawa-Lublin 1966. 